\title{
РОЗВИТОК НОРМАТИВНО-ПРАВОВОГО РЕГУЛЮВАННЯ ОРГАНІЧНОГО АГРОВИРОБНИЦТВА В УКРАЇНІ
}

\section{Є. В. Милованов}

Федерація органічного руху України

вул. Оболонська, 4, оф. 1, м. Київ, 04071, Україна. E-mail: ofu @ organic.com.ua

Проведено ретроспективний аналіз ключових регулювань Євросоюзу щодо органічного виробництва і маркування органічної продукції та детальних правил іх імплементації, а також наведено стислий аналіз попередніх досліджень автора з цієї проблематики. Розглянуто новий Регламент Європейського Парламенту і Ради ЄС та подано короткий опис основних нововведень, що містяться у ньому. Зазначено, що нові положення органічного регулювання покликані сприяти сталому розвитку органічного виробництва в СС та націлені на забезпечення чесної конкуренції для виробників, всіх операторів, запобігання шахрайству та несправедливій практиці, а також на підвищення споживчої довіри до органічних продуктів. Проаналізовано нове законодавство України, що встановлює загальні засади правового регулювання у сфері виробництва, обігу та маркування органічної продукції і $€$ важливим кроком до формування повноцінного правового базису для функціонування органічного сільського господарства та всього органічного сектора нашої країни. Конкретизовано перелік нормативноправових актів, розробка яких передбачена новим законом, які у сукупності мають встановити чіткі та стабільні правила для органічної сфери та мають дозволити органічним виробникам повноцінно конкурувати на внутрішньому та зовнішньому ринках. Визначено, що одним з пріоритетів на сучасному етапі вдосконалення нормативно-правового регулювання органіку $є$ прийняття Державної цільової програми розвитку органічного виробництва в Україні для визначення конкретних етапів, напрямів та механізмів розбудови органічного агровиробництва, ринків та зміцнення експортного потенціалу.

Ключові слова: європейський досвід, вітчизняне законодавство, органічний сектор, нормативно-правове регулювання, органічна продукція, ринок органіку.

\section{РАЗВИТИЕ НОРМАТИВНО-ПРАВОВОГО РЕГУЛИРОВАНИЯ ОРГАНИЧЕСКОГО АГРОПРОИЗВОДСТВА В УКРАИНЕ}

\section{Е. В. Милованов}

Федерация органического движения Украины

ул. Оболонская, 4, оф. 1, г. Киев, 04071, Украина. E-mail: ofu@ organic.com.ua

Осуществлен ретроспективный анализ ключевых регулирований Евросоюза, касающихся вопросов органического производства и маркировки органической продукции, а также детальных правил их имплементации, а также приведен краткий анализ предыдущих исследований автора по этой проблематике. Рассмотрен новый Регламент Европейского Парламента и Совета ЕС и представлено краткое описание основных нововведений/изменений, содержащихся в нем. Указано, что новые положения органического регулирования призваны способствовать устойчивому развитию органического производства в ЕС и нацелены на обеспечение честной конкуренции для фермеров и других операторов, предотвращения мошенничества и несправедливой практики, а также на повышение потребительского доверия к органическим продуктам. Проанализировано новое законодательство Украины, которое устанавливает общие принципы правового регулирования в сфере производства, оборота и маркировки органической продукции и является важным шагом к формированию полноценного правового базиса для функционирования органического сельского хозяйства и всего органического сектора нашей страны. Конкретизирован перечень нормативно-правовых актов, разработка которых предусмотрена новым законом, которые в совокупности должны установить четкие и стабильные правила для органической сферы и позволят органическим производителям полноценно конкурировать на внутреннем и внешнем рынках. Определено, что одним из приоритетов на современном этапе совершенствования нормативно-правового регулирования органика является принятие Государственной целевой программы развития органического производства в Украине для определения конкретных этапов, направлений и механизмов развития органического агропроизводства, рынков и укрепления экспортного потенциала.

Ключевые слова: европейский опыт, украинское законодательство, органический сектор, нормативноправовое регулирование, органическая продукция, рынок органика.

АКТУАЛЬНІСТЬ РОБОТИ. Органічне агровиробництво нині займає чільне місце у системі збалансованого соціально-економічного та екологічного розвитку аграрного сектору національних економік багатьох країн світу. Методи сільського господарства, орієнтовані на найкращі практики 3 погляду на збереження довкілля, збалансоване природокористування, застосування високих стандартів при виробництві сільськогосподарської, харчової продукції та добробут сільського населення, все більше при- вертають увагу, зацікавленість з боку поінформованої громадськості та владних структур.

Для отримання повного комплексу вигод від формування повноцінних органічних систем господарювання у будь-якій державі, необхідне створення міцного нормативно-правового базису для ефективного функціонування органічних товаровиробників. Світовий і вітчизняний досвід розвитку органічного сектору сільськогосподарської галузі свідчить про обмежені можливості розбудови органічного ринку в умовах правової невизначеності та напівлегально- 
го статусу органіку всередині країни. Тому питання формування та вдосконалення «органічного» законодавства, з огляду на високі темпи зростання попиту на світовому органічному ринку та сприятливі агрокліматичні умови в Україні, вимагають посиленої уваги на сучасному етапі розвитку вітчизняного органічного сектору.

Проблематика нормативно-правового забезпечення органічного агровиробництва була у фокусі наукових досліджень вітчизняних науковців: В. І. Артиша [1], Н. А. Берлач [2], М. В. Капштика [3], М. І. Кобця [4], В. О. Мельник [5], О. Ф. Мельничук [6], Н. П. Новак [7], Т. К. Оверковської [8], М. М. Пархоменко [9], Д. В. Піддубної [10], В. П. Рудь [11], Н. В. Фролової [12] та ін. Однак, 3 огляду на динамічність розвитку вітчизняного та світового органічних ринків і постійне оновлення "органічного" законодавства у світі, існує необхідність актуалізації нормативно-правових основ та опрацювання напрямів їх вдосконалення у вітчизняних реаліях господарювання в аграрній галузі.

Метою статті $є$ висвітлення основних етапів та напрямків розвитку нормативно правового регулювання органічного сільського господарства в Україні в сучасних умовах господарювання.

МАТЕРІАЛ I РЕЗУЛЬТАТИ ДОСЛІДЖЕНЬ. Питання повноцінного, орієнтованого на постійний розвиток законодавчого регулювання органічного агровиробництва 3 кожним роком набуває все більшої актуальності та вагомості в умовах постійного підвищення рівня конкуренції на вітчизняному та світовому ринках агропродукції. Товаровиробники країн з високим рівнем правової визначеності органічної сфери, гармонізованої на міжнародному рівні, 3 існуючими системами відповідної підтримки, $є$ більш конкурентоздатними та швидко займають міцні позиції на органічному ринку.

У попередніх дослідженнях нами визначено, що історія успіху європейського органічного руху тісно пов'язана із науково-обгрунтованими фундаментальними підходами до формування дієвої системи забезпечення виробництва, переробки, маркування та ринку органічної продукції, неодмінною та надзвичайно важливою складовою якої є правове обгрунтування [13]. Також було здійснено ретроспективний аналіз становлення законодавства в органічній сфері Європейського Союзу [13].

Зауважимо, що ключовими регулюваннями Свросоюзу, крім Постанови СС № 2092/91 від 24 червня 1991 р., були і все ще залишаються Постанова Ради (СС) № 834/2007 від 28.06.2007 р. про органічне виробництво та маркування органічної продукції [14], Регламент Комісії (СС) №889/2008 від 05.09.2008 р., що визначає детальні правила імплементації Постанови Ради (СС) №834/2007 щодо органічного виробництва та маркування органічної продукції стосовно органічного виробництва, маркування і контролю [14] та Регламент Комісії (СС) № 1235/2008, що встановлює детальні правила для імплементації Постанови Ради (СС) №834/2007 стосовно заходів для імпортування органічної продукції з третіх країн [15]. Ці регулювання вступили в силу ще 31 січня 2009 р. та поширювались на всі суб'єкти господарювання, які виробляють та/або реалізовують органічні продукти на ринках ЄС. Потреба їх прийняття була продиктована потребою чіткішого визначення цілей, принципів та правил органічного виробництва 3 метою сприяння прозорості, встановленню довіри споживачів та гармонізованому сприйняттю концепції органічного виробництва [13].

У червні 2018 р. в офіційному віснику Свропейського Союзу було опубліковано новий Регламент Свропейського Парламенту і Ради (СС) № 2018/848 від 30.05.2018 р. про органічне виробництво й маркування органічних продуктів і скасування регламенту Ради (ЄС) № 834/2007. Цей Регламент встановлює принципи органічного виробництва та визначає правила стосовно органічного виробництва, пов'язаної з ним сертифікації та використання позначень, які стосуються органічного виробництва, в маркуванні та рекламних матеріалах, а також правила щодо додаткового контролю, окрім контролю, передбаченого в Регламенті (СС) 2017/625.

Новий регламент визначається як коригуючий, але дане положення скасовує Постанову № 834/2007 і вводиться в дію 31 січня 2021 р. Нижче наведемо короткий опис основних нововведень, що містяться в ньому:

гідропонне виробництво, яке полягає у розміщенні коренів деяких рослин у поживному розчині, заборонене;

- виробництво переробленої органічної їжі не має включати продукти, що містять або складаються 3 наноматеріалів;

деякі продукти можуть бути включені в органічне виробництво у тій мірі, в якій вони можуть бути виготовлені за допомогою природних технологій виробництва. Ці продукти наведені в додатку I до нового регламенту;

створено систему групової сертифікації для дрібних фермерів та операторів 3 метою зниження витрат на інспектування та сертифікацію і адміністративних обмежень, зміцнення місцевих мереж, сприяння розвитку роздрібної торгівлі та забезпечення рівних умов для операторів 3 третіх країн;

- за певних умов ферма може виробляти як органічну, так і конвенційну та не органічну продукцію;

оператори та групи операторів підлягають перевірці відповідності щонайменше один раз на рік. У випадку, коли не було виявлено невідповідностей протягом 3-х років поспіль, інтервал між наступними перевірками становитиме два роки;

- не пізніше 31 грудня 2024 р. Комісія має подати до Свропейського Парламенту та Ради доповідь щодо наявності продуктів та речовин, не дозволених для використання в органічному виробництві, та про оцінку існуючих національних правил. Цей звіт може супроводжуватися пропозиціями до законодавства щодо подальшої гармонізації.

Старі правила органічного виробництва, були нерівними в межах Свросоюзу, оскільки вони включали широкий спектр різноманітних практик та винятків. Крім того, принцип еквівалентності щодо імпортованих органічних продуктів створив ситуа- 
цію, коли різні стандарти застосовуються до різних виробників з однієї країни.

Нові положення органічного регулювання покликані сприяти сталому розвитку органічного виробництва в СС та націлені на забезпечення чесної конкуренції для фермерів та операторів, запобігання шахрайству та несправедливій практиці та підвищення споживчої довіри до органічних продуктів.

Отже, Євросоюз постійно системно працює над вдосконаленням "органічного" законодавства та оновлює діючі регламенти з метою оптимізації виробничо-торгівельних відносин у сфері органіку та прискорення темпів розвитку одного 3 найбільш перспективних ринків органічної продукції у Європі та всьому світі. У провідних європейських країнах $\epsilon$ чітке усвідомлення взаємозв'язку та взаємозалежності між повноцінним нормативно-правовим регулюванням органіку та темпами зростання даного прогресивного напряму сільськогосподарського виробництва, що, у свою чергу, здатне реально підвищити ВВП кожної країни-члена СС та забезпечити синергетичний ефект у рамках Свросоюзу.

Незважаючи на недосконалість законодавства та труднощі економічного становища вітчизняних агровиробників, органічний сектор сільськогосподарської галузі в Україні постійно нарощує темпи як розвитку агровиробництва, так і торгівлі. Зокрема, доказом цьому є те, що за останні 10 років відбулися цілком прогнозовані позитивні зміни: зросли площі сільськогосподарських угідь, зайняті під органічним виробництвом (з 270 тис. га у 2008 р. до 420 тис. га у 2017 р. - на 55,5\%), зросло число органічних господарств (з 118 у 2008 р. до 375 у 2017 р. - у 4,2 рази), значно виріс обсяг органічного ринку (з 0,6 млн євро у 2008 р. до 33,0 млн євро у 2018 р. - у 55 разів), експорт органічної сільськогосподарської продукції у 2018 р. у вартісному виразі склав 104 млн євро, ставши найбільшим європейським постачальником органічної сировини до країн Свропейського Союзу [16]. Україна має можливість зміцнити свої позиції повноцінного гравця на міжнародному ринку органічної продукції (i, звісно, не лише сировини, але й готових продуктів), якщо вітчизняні виробники та експортери діятимуть у сприятливих, прозорих інституційно-правових умовах на території своєі країни та зовнішніх ринках, з максимальною гармонізацією з європейськими та світовими стандартами і регулюваннями.

Перш за все, варто зазначити, що кожному громадянину Конституцією України гарантована не лише безпека життя, але й безпека здоров'я та харчування. Основний Закон нашої держави, зокрема, містить положення, пов'язані з даними гарантіями [17]:

1) Стаття 3. Людина, iї життя і здоров'я, честь i гідність, недоторканність і безпека визнаються в Україні найвищою соціальною цінністю.

2) Стаття 16. Забезпечення екологічної безпеки і підтримання екологічної рівноваги на території України, подолання наслідків Чорнобильської катастрофи - катастрофи планетарного масштабу, збереження генофонду Українського народу є обов'язком держави.
3) Стаття 42. ... Держава захищає права споживачів, здійснює контроль за якістю і безпечністю продукції та усіх видів послуг і робіт, сприяє діяльності громадських організацій споживачів.

4) Стаття 50. Кожен має право на безпечне для життя і здоров'я довкілля та на відшкодування завданої порушенням цього права шкоди. Кожному гарантується право вільного доступу до інформації про стан довкілля, про якість харчових продуктів і предметів побуту, а також право на іiі поширення. Така інформація ніким не може бути засекречена [17].

Ретроспективний аналіз вітчизняного нормативно-правового забезпечення органічної сфери, проведений у попередніх дослідженнях [13], свідчить про наявність суттєвих зрушень у формуванні законодавчого базису для подальшого розвитку органіку в нашій державі.

У 2016 р. за ініціативи фахівців органічного ринку, Міністерством аграрної політики та продовольства України спільно з Федерацією органічного руху України та іншими представниками сектору був розроблений Проект Закону України "Про основні принципи та вимоги до органічного виробництва, обігу та маркування органічної продукції" (зареєстрований у Верховній Раді України під № 5448 від 24.11.2016 р.). Основною метою закону була адаптація вимог вітчизняного органічного нормативноправового поля до законодавства ЄС.

15 березня 2018 р. вищезгаданий Проект Закону розглядався на засіданні Комітету з питань аграрної політики та земельних відносин ВР України. Було прийнято одноголосне рішення рекомендувати Верховній Раді України прийняти даний законопроект у повторному першому читанні.

10 липня 2018 р. Верховна Рада України прийняла Закон України "Про основні принципи та вимоги до органічного виробництва, обігу та маркування органічної продукції" [18]. Закон встановлює загальні засади правового регулювання у сфері органічного виробництва, обігу та маркування органічної продукції. Передбачається, що імплементація нового закону стимулюватиме динамічний розвиток органічного виробництва в Україні, сприятиме підвищенню конкурентоспроможності вітчизняного органіку та розширенню зовнішніх ринків для його збуту. Також вагомим результатом має стати максимальна відповідність органічного виробництва в Україні міжнародним вимогам і стандартам. Завдяки цьому вітчизняні споживачі отримуватимуть дійсно якісний перевірений органічний продукт, а українська експортна продукція приноситиме додаткові валютні надходження і зміцнюватиме позитивний імідж держави на світовому ринку.

Згаданий закон України $є$ важливим кроком на шляху до формування повноцінного правового базису для вітчизняного органічного агровиробництва. Але, 3 огляду на світовий досвід нормативноправового регулювання та вітчизняні реалії господарювання, український органік потребує подальшого прийняття нових та вдосконалення існуючих регулюючих документів, які забезпечуватимуть якісніше та комплексне наповнення нормативно-правового поля для систем органічного господарювання. 
3 огляду на вищесказане, вбачається за необхідне конкретизувати перелік нормативно-правових актів,

розробка яких передбачена даним законом (табл. 1).

Таблиця 1 - Перелік нормативно-правових актів, розробка яких передбачена Законом України «Про основні принципи та вимоги до органічного виробництва, обігу та маркування органічної продукції»

\begin{tabular}{|c|c|c|c|}
\hline $\begin{array}{l}\text { № } \\
\text { I/II }\end{array}$ & Назва нормативно-правового акту & $\begin{array}{l}\text { Стаття } \\
\text { Закону }\end{array}$ & Затверджує \\
\hline 1. & Затвердження державного логотипу для органічної продукції. & стаття 11 & Мінагрополітики \\
\hline 2. & $\begin{array}{l}\text { Порядок (детальні правила) органічного виробництва та обігу органічної продук- } \\
\text { ції, } \\
\text { в тому числі: } \\
\text { особливості застосування винятків; } \\
\text { особливості ведення паралельного виробництва; } \\
\text { особливості зберігання окремих видів органічної продукції; } \\
\text { особливості перевезення окремих видів органічної продукції; } \\
\text { особливості маркування окремих видів органічної продукції). }\end{array}$ & $\begin{array}{l}\text { стаття } 13 \\
\text { стаття } 24 \\
\text { стаття } 26 \\
\text { стаття } 32 \\
\text { стаття } 33 \\
\text { стаття } 34\end{array}$ & $\begin{array}{l}\text { Кабінет } \\
\text { Міністрів } \\
\text { України }\end{array}$ \\
\hline 3. & $\begin{array}{l}\text { Перелік речовин (інгредієнтів, компонентів), які дозволяється використовувати у } \\
\text { процесі органічного виробництва та які дозволені до використання в гранично } \\
\text { допустимих кількостях, зокрема: } \\
\text { 1) засоби захисту рослин; } \\
\text { 2) добрива і речовини для покращення грунту; } \\
\text { 3) неорганічні кормові матеріали рослинного походження, кормові матеріали } \\
\text { тваринного і мінерального походження та деякі речовини, які застосовуються у } \\
\text { годівлі тварин; } \\
\text { 4) кормові та технологічні добавки; } \\
\text { 5) продукти для очищення і дезінфекції ставків, кліток, будівель і споруд, які ви- } \\
\text { користовуються у тваринництві; } \\
\text { 6) продукти для очищення і дезінфекції будівель і споруд, які використовуються у } \\
\text { рослинницті; } \\
\text { 7) інші речовини (інгредієнти, компоненти). }\end{array}$ & стаття 14 & $\begin{array}{l}\text { Мінагрополітики } \\
\text { України }\end{array}$ \\
\hline 4. & $\begin{array}{l}\text { Порядок сертифікації органічного виробництва та/або обігу органічної продукції, } \\
\text { (в тому числі: } \\
\text { особливості надання згоди органами сертифікації на використання під час вироб- } \\
\text { ництва операторами неорганічних інгредієнтів, тварин, насіння та/або садивного } \\
\text { матеріалу } \\
\text { порядок видачі сертифіката, його дубліката та його форма). }\end{array}$ & $\begin{array}{l}\text { стаття } 24 \\
\text { стаття } 24 \\
\text { стаття } 27 \\
\end{array}$ & $\begin{array}{l}\text { Кабінет } \\
\text { Міністрів } \\
\text { України }\end{array}$ \\
\hline 5. & $\begin{array}{l}\text { Вимоги до матеріально-технічної бази та інших об’єктів інфраструктури, необ- } \\
\text { хідних для виконання функцій із сертифікації органічного виробництва та/або } \\
\text { обігу органічної продукції. }\end{array}$ & стаття 28 & $\begin{array}{l}\text { Мінагрополітики } \\
\text { України }\end{array}$ \\
\hline 6. & Форма заявки на включення до Реєстру органів сертифікації. & стаття 28 & Мінагрополітики \\
\hline 7. & $\begin{array}{l}\text { Порядок звітування органів сертифікації центральному органу виконавчої влади, } \\
\text { що забезпечує формування та реалізацію державної аграрної політики, та центра- } \\
\text { льному органу виконавчої влади, що забезпечує формування та реалізацію держа- } \\
\text { вної аграрної політики, про видані ним сертифікати. }\end{array}$ & стаття 28 & $\begin{array}{l}\text { Мінагрополітики } \\
\text { України }\end{array}$ \\
\hline 8. & Порядок розгляду апеляцій на рішення органів сертифікації. & стаття 28 & Мінагрополітики \\
\hline 9. & Порядок ведення Переліку органів іноземної сертифікації. & стаття 29 & Мінагрополітики \\
\hline 10. & $\begin{array}{l}\text { Порядок підтвердження спеціальних знань інспектора з органічного виробництва } \\
\text { та/або обігу органічної продукції у сфері органічного виробництва. }\end{array}$ & стаття 30 & $\begin{array}{l}\text { Мінагрополітики } \\
\text { України }\end{array}$ \\
\hline 11. & $\begin{array}{l}\text { Порядок ведення Реєстру операторів, Реєстру органів сертифікації та Реєстру } \\
\text { органічного насіння і садивного матеріалу. }\end{array}$ & стаття 31 & $\begin{array}{c}\text { Кабінет } \\
\text { Міністрів } \\
\text { України }\end{array}$ \\
\hline 12. & $\begin{array}{l}\text { Порядок, періодичність декларування та подання зведених матеріалів щодо обся- } \\
\text { гів органічної продукції, яка вводиться в обіг органами сертифікації центрально- } \\
\text { му органу виконавчої влади, що забезпечує формування та реалізацію державної } \\
\text { аграрної політики, та центральному органу виконавчої влади, що забезпечує фор- } \\
\text { мування та реалізацію державної аграрної політики. }\end{array}$ & стаття 36 & $\begin{array}{l}\text { Мінагрополітики } \\
\text { України }\end{array}$ \\
\hline
\end{tabular}
Джерело: розроблено на основі [18].

В Україні сільськогосподарські угіддя, на яких займаються органічним виробництвом, за останні 15 років зросли у 2,5 рази і продовжують зростати. Завдяки прийняттю нового закону, державні підтримці, яка має з'явитися, вітчизняний органічний сектор має продовжувати розвиватися, а споживачі зможуть більше довіряти та бути впевненішими щодо безпечності українських сертифікованих органічних продуктів, які вони купують і які легше буде іден- тифікувати завдяки визначеному маркуванню.

Відповідно до статті 11 Закону України «Про основні принципи та вимоги до органічного виробництва, обігу та маркування органічної продукції», наказом Міністерства аграрної політики та продовольства України від 22 лютого 2019 року №67 затверджено державний логотип для органічної продукції (рис. 1) та його технічний опис. Наказ було зареєстровано в Міністерстві юстиції України 14 
березня 2019 р. за №261/33232 [19]. Разом 3 тим, втратив чинність попередній наказ Мінагрополітики від 25 грудня 2015 р. №495 «Про затвердження державного логотипу для органічної продукції (сировини)» [20].

Вже понад три роки вітчизняні аграрії не можуть використовувати згаданий логотип при маркуванні продукції через правовий вакуум в органічному секторі України. Адже відсутні відповідні підзаконні акти та державне регулювання органічного вироб-

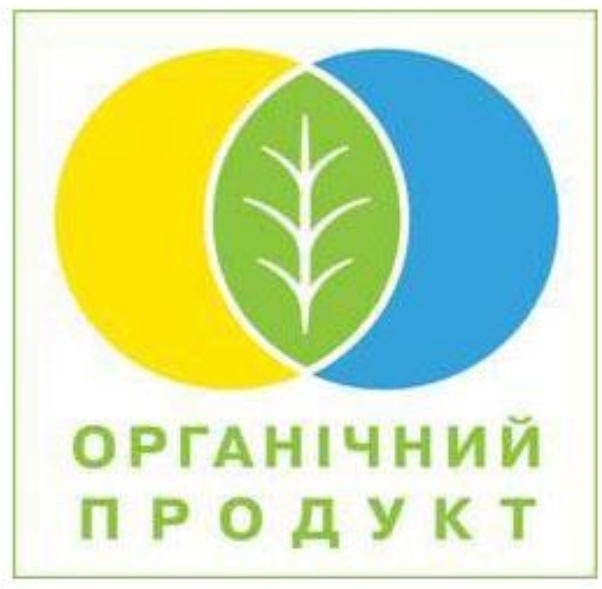

ництва, імплементація якого дозволило б виробникам використовувати державний логотип при маркуванні органічних продуктів. Новий органічний закон $\epsilon$ важливим кроком у даному питанні, однак процес підготовки відповідних документів ще триває, то ж маємо надію, що наприкінці 2019 р. український споживач може побачити нове маркування на сертифікованій органічній продукції вітчизняного виробництва.

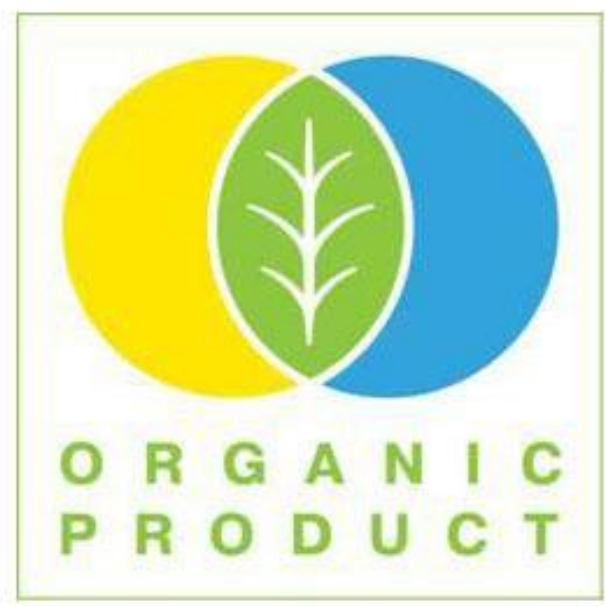

Рисунок 1 - Державний логотип для органічної продукції [20]

Важливим нововведенням відповідно нового закону є те, що до 2 серпня 2019 р. передбачається створення та введення в дію нового Державного реєстру органів сертифікації у сфері органічного виробництва та обігу органічної продукції. Для включення до Реєстру органи сертифікації мають відповідати вимогам нового законодавства про органічне виробництво. Нарешті ефективний контроль передбачено не лише за виробниками, але й за сертифікаційними організаціями. За порушення вони нестимуть відповідальність, аж до вилучення з реєстру та припинення права на сертифікаційну діяльність в органічному сільському господарстві. Так, підприємства, установи чи організації сертифікації органічного виробництва повинні [21]:

- мати акредитацію відповідно до Закону України «Про акредитацію органів 3 оцінки відповідності» у сфері органічного виробництва та/або обігу продукції за однією або кількома 3 таких галузей: органічне рослинництво (у т.ч. насінництво та розсадництво), органічне тваринництво (у т.ч. птахівництво, бджільництво), заготівля органічних об'єктів рослинного світу, органічне грибівництво (у т.ч. вирощування органічних дріжджів), органічна аквакультура, виробництво органічних морських водоростей, виробництво органічних харчових продуктів (у т.ч. органічне виноробство), виробництво органічних кормів;

- бути юридичною особою, зареєстрованою згідно із законодавством України;

- не бути оператором;

- мати належну матеріально-технічну базу та інші об'єкти інфраструктури, необхідні для вико- нання функцій із сертифікації органічного виробництва та/або обігу органічної продукції;

- мати змогу підтвердити відповідний рівень компетентності персоналу у сфері сертифікації органічного виробництва та/або обігу органічної продукції;

- мати принаймні одного інспектора з відповідної галузі органічного виробництва та/або обігу органічної продукції, який працює на постійній основі [21].

Для внесення до Реєстру мають подаватися наступні документи: заява; копія атестата про акредитацію; копія свідоцтва про реєстрацію підприємства, установи, організації чи їхнього підрозділу; копія статуту підприємства, установи, організації чи їхнього підрозділу; перелік співробітників та документи, що підтверджують рівень компетентності персоналу у сфері сертифікації органічного виробництва та/або обігу органічної продукції. Документи подаються до Мінагрополітики 3 дня введення в дію Закону України «Про основні принципи та вимоги до органічного виробництва, обігу та маркування органічної продукції». Рішення про внесення чи відмову у внесенні до Реєстру органів сертифікації приймається Мінагрополітики протягом 10 днів 3 дня отримання зазначених документів [21].

Крім того, вищенаведеним законом передбачено створення Державного реєстру операторів - офіційного переліку операторів, які здійснюють органічне виробництво та/або обіг органічної продукції відповідно до вимог законодавства у сфері органічного виробництва, обігу та маркування органічної продукції, що міститься в інформаційній базі даних. Да- 
ний реєстр дасть споживачам чітке розуміння органічного виробника та органічного бренду, оскільки отримають вільний доступ до даного офіційного переліку. Оператори при цьому нестимуть відповідальність за маркування продукції державним логотипом для органічної продукції або використання в маркуванні позначень і написів «органічний», «біодинамічний», «біологічний», «екологічний», «органік» і будь-яких однокорінних похідних від цих слів 3 приставками «біо», «еко» тощо будь-якими мовами, за відсутності сертифікату у вигляді штрафів.

Також законом передбачено створення та ведення Державного реєстру органічного насіння і садивного матеріалу - офіційного переліку органічного насіння і садивного матеріалу, придатного для використання відповідно до вимог даного законодавства. Даний реєстр - це спроба вирішення ще однієї болючої проблеми вітчизняних органічних виробників, яка стосується пошуку органічного насіння та забезпечення прозорості, прослідковуваності щодо виробництва, обсягів та розміщення наявного органічного насіння. В Україні наразі є лише декілька виробників органічного садивного матеріалу, а промислове органічне виробництво насіння у нашій країні знаходиться на стадії становлення. Здебільшого посівний матеріал органічні агровиробники готують самостійно. Крім цього, при органічному виробництві в Україні практикують використання конвенційного, але не протруєного хімічними препаратами насіння.

Всі три реєстри, що мають запрацювати відповідно нового закону, є саме тими практичними заходами, які мають сприяти наведенню ладу у вітчизняному секторі органічного сільського господарства. Ключовий постулат нового закону - інституціоналізація всієї сфери органічного виробництва, а не просто готової продукції, як це було закладено у попередньому законодавстві. Тобто, передбачається контроль вигробництва органіку на всіх стадіях, а не лише перед потраплянням на полиці супермаркетів.

Новий «органічний» закон потенційно може стати міцною основою для розбудови вітчизняного органічного сектору, який потребує чітких та стабільних правил та дозволить органічним виробникам повноцінно конкурувати на внутрішньому та зовнішньому ринках. Однак, при цьому, вже зараз, не зважаючи на політичну турбулентність в державі, необхідно активізувати роботу по подальшому доопрацюванню згаданого закону, так як навіть за час, що минув 3 моменту його прийняття, фахівці відмітили певні неузгодження, суперечності деяких положень закону з міжнародною практикою та діючим вітчизняним законодавством.

I все ж варто зауважити, що завдяки новим правилам споживачі, які купуватимуть продукт із вітчизняним органічним логотипом, зможуть бути більш впевнені не лише в тому, що вони отримають якість європейського рівня, але й у тому, що можна відслідкувати повну історію походження органічного продукту.

Аналізуючи досягнення України у сфері правового регулювання органічної сфери, слід згадати про основні стратегічні напрямки, задекларовані у Стра- тегіï розвитку аграрного сектору «3+5» [22], яка представлена Міністерством аграрної політики України у 2016 р. Дана стратегія є офіційною та грунтується на: 3 пріоритетах - реформі системи державної підтримки з акцентом на дрібних фермерах, завершенні земельної реформи та реформі державних підприємств; 5 головних напрямках - розвитку ринків збуту, органічному виробництві та нішевих культурах, розвитку сільських територій, зрошенні та безпеці харчової продукції. Тобто, розвиток органічного виробництва $є$ основним пріоритетом для вітчизняної аграрної сфери, поряд із безпекою харчової продукції, яка тісно пов'язана з органіком. Необхідно зробити наступний рішучий крок перейти від законодавчого закріплення до конкретних дій щодо організаційної та фінансової підтримки вітчизняних органічних виробників [13].

На загальному фоні позитивних тенденцій у сфері інституційно-правового регулювання вітчизняної органічної сфери, варто відзначити необхідність формування та реалізації додаткових регулюючих документів спрямованих на довгостроковий розвиток органіку в Україні. Одним з пріоритетів вважаємо розробку та прийняття спочатку Концепції Державної цільової програми розвитку органічного виробництва в Україні. А після їі схвалення Кабінетом Міністрів України, відразу ж, - прийняття власне самої Державної цільової програми розвитку органічного виробництва в Україні, де необхідно визначити конкретні етапи, напрями та механізми розбудови органічного виробництва, ринку та експортного потенціалу держави. Основними завданнями даної стратегії мають бути:

- обгрунтування фінансової підтримки органічного виробництва на державному, регіональному та локальному рівнях;

- формування системи стимулювання експорту органічної продукції;

- визначення основних засад розробки та впровадження національної інформаційної кампанії з органічного виробництва та стимулювання споживання органічної продукції, в т.ч. в закладах освіти, лікарнях, в армії та державних установах;

- формування методології відшкодування витрат на інспектування та сертифікацію органічним виробникам;

- створення системи консультативного обслуговування агровиробників щодо органічних технологій сільського господарства;

- визначення умов співфінансування участі органічних операторів на національних та міжнародних заходах, виставках та ярмарках;

- формування заходів 3 підвищення доступності органічного насіння на внутрішньому ринку;

- обгрунтування спрощення процедур державного адміністрування щодо органічного виробництва;

- встановлення політики залучення зацікавлених сторін до всіх заходів, пов'язаних з розвитком вітчизняного органічного сектору;

- формування системи науково-прикладних досліджень органічного сільського господарства в Україні та світі;

- визначення напрямів розвитку освітніх програм 
підготовки кваліфікованих працівників у сфері органічного сільського господарства.

Роль Державної цільової програми розвитку органічного виробництва в Україні в системі розбудови вітчизняного органічного сільського господарства представлено на рис. 2.

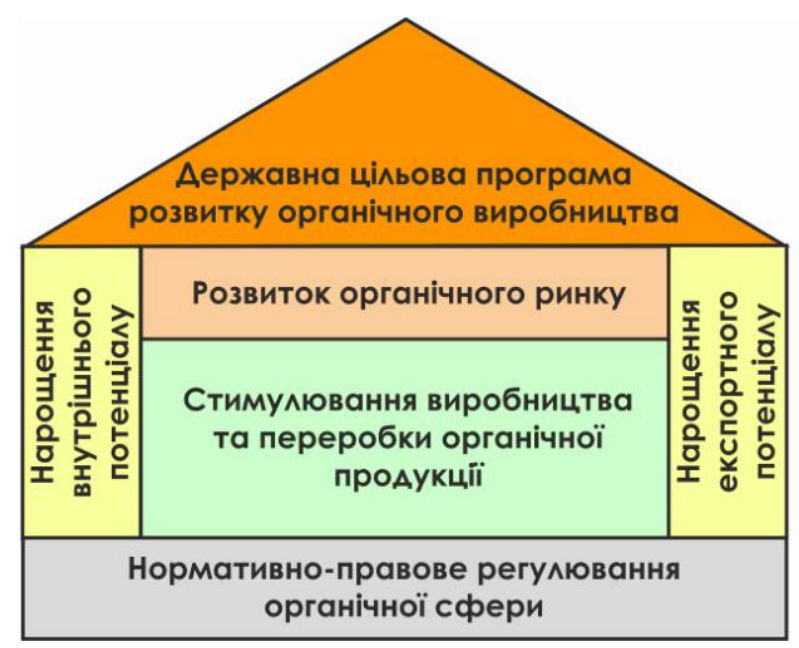

Рисунок 2 - Роль Державної цільової програми розвитку органічного виробництва в Україні в системі розбудови вітчизняного органічного сільського господарства

Вищенаведена система передбачає, що основним стимулом для фермерських господарств та інших сільськогосподарських підприємств для переходу на органічні практики будуть кращі маркетингові можливості та преміальні ціни на органічну продукцію. Це, в свою чергу, сприятиме розбудові внутрішнього ринку органіку, який, крім цього, потребує конкретних заходів підтримки та стимулювання з боку держави. Повноцінне нарощення потенціалу органічного агровиробництва відбуватиметься 3 формуванням та реалізацією конкретних заходів з підвищення рівня обізнаності громадськості щодо особливостей, переваг органіку на національному рівні. Ці заходи підтримуються механізмом налагодження співпраці та зв'язків між приватним та державним секторами. Нарощення експортного потенціалу, у свою чергу потребує міцних міжнародних зв'язків та гармонізації вітчизняного законодавства із провідним світовим на всіх рівнях.

Зауважимо, що в основі наведеної системи лежить інституціонально-правове забезпечення всіх процесів та дій, що є своєрідним "фундаментом" для довгострокового розвитку вітчизняного органічного сектору. Міжнародний досвід та вітчизняна практика свідчать про об'єктивну необхідність подібного базису, без якого прискорення розбудови органічної сфери є примарною перспективою.

Розробка концепцій та програм розвитку на регіональному та локальному рівнях також є важливими заходами, які, у свою чергу, в найвищій мірі є конкретизацією індивідуальних дій та встановлених пріоритетів розбудови багатофункціональних систем органічного виробництва, спрямованих на сталий розвиток національної економіки та суспільства у цілому. Важливим кроком у даному контексті є розроблений Федерацією органічного руху України, під керівництвом автора цієї статті, проект Концепції державної Програми розвитку органічного виробництва в Україні [14] за дорученням Міністерства аграрної політики України ще в листопаді 2008 року.

У згаданому документі були задекларовані основні положення майбутньої Програми, яка формувалася для забезпечення сталого розвитку аграрного комплексу України шляхом розвитку та підтримки ведення органічного виробництва як одного з пріоритетних напрямків реалізації державної аграрної політики. Основні постулати даної Концепції використовувалися Мінагрополітики при складанні наступних стратегій та програм розвитку аграрного сектору країни, а також допомогли виділити органічний напрямок ключовим в актуальних питаннях екологізації агровиробництва, підвищення добробуту селян та зміцнення експортного потенціалу нашої держави [13]. Дані напрацювання можуть стати базовим підгрунтям для розробки нової Програми розвитку органічного виробництва як на державному, так і регіональному рівнях.

ВИСНОВКИ. Таким чином, розвиток нормативно-правового регулювання органічного сектору в Україні $є$ найбільш пріоритетним напрямом дій на шляху формування надійної основи для побудови найбільш перспективної системи агровиробництва, яка здатна прискорити не лише розбудову аграрної галузі, але й усієї національної економіки України вже у найближчій перспективі. Постійне оновлення, «апгрейд» законодавства в органічній сфері, при цьому, є важливим процесом для всіх іiї учасників, а також містить ряд важливих регулювань, що здатні упорядкувати інституціональне середовище функціонування органічних операторів на вітчизняному ринку та сформувати міцну основу для зміцнення i нарощення експортного потенціалу українського органіку.

Перспективами подальших досліджень є науково-методичне обгрунтування формування конкретних концепцій та програм розвитку органічного агровиробництва на рівні областей та районів України для реалізацій системи заходів підтримки вітчизняних сільгоспвиробників на шляху освоєння одного 3 найбільш прогресивних i перспективних методів агровиробництва у світі.

\section{ЛІТЕРАТУРА}

1. Артиш В. I. Удосконалення системи державного регулювання виробництва органічної продукції в Україні. Науковий вісник наи. університету біоресурсів $i$ природокористування Украӥни. 2010. Вип. 145. С. 365-370.

2. Берлач Н. А. Вдосконалення спеціальної нормативно-правової бази - пріоритетний чинник розвитку органічного сільського господарства в Україні. Форум права. 2010. № 1. С. 19-23.

3. Капштик М. В. Нормативно-правове забезпечення органічного виробництва в Україні: проблеми та перспективи. Агроекологічний журнал. 2012. № 1. C. 25-31. 
4. Кобець М. І. Органічне землеробство в контексті сталого розвитку. Проект «Аграрна політика для людського розвитку». К., 2004. 22 с.

5. Мельник В. О. Правове регулювання органічного сільськогосподарського виробництва в Україні : дис. канд. юр. наук: 12.00 .06 «Земельне право; аграрне право; екологічне право; природо-ресурсне право» (юридичні науки); Національний університет біоресурсів і природокористування України. К., 2018. 224 c.

6. Мельничук О. Ф., Мельничук М. О. Правове регулювання виробництва органічної сільськогосподарської продукції в Україні. Економіка. Фінанси. Менеджмент: актуальні питання науки і практики. 2017. № 5. C. 98-108.

7. Новак Н. П. Формування і реалізація стратегічних засад розвитку органічного виробництва у сільськогосподарських підприємствах. Причорноморські економічні студї. 2016. Вип. 4. С. 74-77.

8. Оверковська Т. К. Правові ознаки органічного виробництва сільськогосподарської продукції в Україні. Підприємництво, господарство $i$ право: загальноукраӥнський науково-практичний господарсько-правовий журнал. 2017. № 11. С. 94-98.

9. Пархоменко М. М. Правове регулювання органічного виробництва в Україні. Форум права. 2011. № 4. С. 546-552.

10. Піддубна Д. В. Правове забезпечення захисту органічної продукції від генетично модифікованих організмів в Україні : монографія. Донец. юрид. ін-т. Кривий Ріг: Роман Козлов, 2015. 371 с.

11. Рудь В. П. Інституційно-правове регулювання органічного овочівництва. Інтелект XXI. 2018. № 4. C. 82-86.

12. Фролова Н. В. Основні правові засади органічного виробництва. Порівняльно-аналітичне право. 2016. № 6. С. 142-145.

13. Милованов Є. В. Правові засади регулювання органічного виробництва в країнах СС. Економіка АПК. 2018. № 5. С. 117-125.

14. Довідник стандартів ЄС щодо регулювання органічного виробництва та маркування органічних продуктів; за ред. к.е.н. С. Милованова, к.с-г.н. С. Мельника, к.с-г.н. О. Демидова, В. Жилкіна, I. Колесник, А. Коняшина, В. Ніщети, к.е.н. В. Ткачука. Львів: ЛА «Піраміда», 2008. 204 с.

15. Довідник стандартів ЄС щодо регулювання органічного виробництва та маркування органічних продуктів : Кн. 2; за ред. к.е.н. С. Милованова, к.с-г.н. С. Мельника, к.с-г.н. О. Демидова, С. Іващука, І. Колесник, А. Коняшина, М. Нетеси, В. Ніщети, М. Поєдинка. Львів: ЛА «Піраміда», 2010. 176 с.

16. Офіційний сайт Федерації органічного руху України. URL

http://organic.com.ua/uk/homepage/2010-01-26-13-42-

29 (дата звернення: 31.05 .2019 р.)

17. Конституція України. Відомості Верховної Ради України (ВВР), 1996, № 30, ст. 141. URL : http://zakon.rada.gov.ua/laws/show/254к/96-вр (дата звернення: 29.05.2019 р.)

18. Про основні принципи та вимоги до органічного виробництва, обігу та маркування органічної продукції : Закон України від 10 липня 2018 р. № 2496-VIII База даних "Законодавство України" / ВР України.

URL : http://zakon.rada.gov.ua/laws/show/2496-19 (дата звернення: 23.05.2019 р.).

19. Про затвердження державного логотипа для органічної продукції: Наказ Міністерства аграрної політики та продовольства України від 22.02.2019 р. № $67 . \quad$ URL

https://zakon.rada.gov.ua/laws/show/z0261-19 (дата звернення: 19.05.2019 р.).

20. Про затвердження державного логотипу для органічної продукції (сировини) : Наказ Міністерства аграрної політики та продовольства України від 25.12.2015 p. № 495. URL : http://zakon.rada.gov.ua/laws/show/z0099-16\#n15 (дата звернення: 24.05.2019 р.).

21. «Органічний» Закон: Встановлені вимоги до органів сертифікації органічної продукції: Офіційний сайт Міністерства аграрної політики та продовольства України. URL : http://www.minagro.gov.ua/node/26227 (дата звернення: 12.05.2019 р.)

22. Стратегія розвитку аграрного сектору «3+5». Офіційний сайт Міністерства аграрної політики та продовольства України. URL : http://minagro.gov.ua/system/files/3\%205\%20final.pdf (дата звернення: 23.05.2019 р.).

23. Довідник міжнародних стандартів для органічного агровиробництва / Навчально-координаційний центр сільськогосподарських дорадчих служб; за ред. М. В. Капштика та О. О. Котирло. К. : СПД Горобець Г. С., 2007. 356 с.

24. Довідник стандартів ЄС щодо регулювання органічного виробництва та маркування органічних продуктів : Кн. 6; за ред. к.е.н. С. Милованова. Львів: ВК «АРС», 2018. 204 с.

25. Мельник В. О. Зарубіжний досвід правового регулювання органічного виробництва (порівняльно-правовий аспект). Науковий вісник Національного університету біоресурсів і природокористування України. 2014. Вип. 197. Ч. 2. С. 79-90.

26. Регіональна підтримка органічного виробництва в Україні [С. Милованов, М. Мартинюк, О. Ковальова, О. Ходаківська та ін.]; за ред. к.е.н. Є. Милованова. К. : Органік Прінт, 2018. 56 с.

27. Official website of European Union law. URL : http://eur-lex.europa.eu (дата звернення: 28.11.2018 p.).

28. Willer H., Lernoud J. The World of Organic Agriculture. Statistics and Emerging trends. FiBL\&IFOAM - Organic International. Germany: Medienhaus Plump, 2019. - 352 p. 


\section{REGULATORY DEVELOPMENT ORGANIC AGRICULTURAL PRODUCTION IN UKRAINE}

\section{E. Milovanov}

Organic Federation of Ukraine

vul. Obolonska, 4, office 1, Kyiv, 04071, Ukraine. E-mail: ofu@ organic.com.ua

Purpose. The purpose of the article is to highlight the main stages and directions of development of legal regulation of organic agriculture in Ukraine in the modern economic conditions. Methodology. The research methodology was based on the systematic approach and comprehensive analysis of the development of regulatory and legal regulation of organic farming in Ukraine as well as graphical, analytical, logical, comparative methods, methods of analysis and synthesis. Findings. The article states that the International and Ukrainian experience in the development of the organic sector of the agricultural sphere indicates the limited development opportunities of the organic market in the context of legal uncertainty and semi-legal status of organic within the country. It is argued that the issue of full-fledged, continuous development of legislative regulation of organic agricultural production is becoming increasingly relevant and significant every year in the context of the constant increase in competition in the Ukrainian domestic and global agricultural markets. Retrospective analysis of the key EU regulations on organic production and labeling of organic products and detailed rules for their implementation has been carried out, and brief analysis of the author's previous research on this subject has been given. The new Regulation of the European Parliament and the Council of the European Union was considered and brief description of the main innovations contained in it was presented. It is indicated that the new provisions of organic regulation are designed to promote the sustainable development of organic production in the EU and are aimed at the ensuring fair competition for farmers and other operators, preventing fraud and unfair practices, as well as increasing consumer awareness and confidence in organic products. The attention is focused on the fact that the European Union is constantly working systematically to improve the "organic" legislation and update the existing regulations in order to optimize production and trade relations in the field of organic and accelerate the development of one of the most promising organic markets in Europe and in the whole world. Analyzed the new legislation of Ukraine, which establishes the general principles of legal regulation in the sphere of production, circulation and labeling of organic products and it is important step towards the formation of the full-fledged legal basis for the functioning of organic agriculture and the whole organic sector of Ukraine. Originality. The list of normative legal acts, the development of which is stipulated by the new law, which together to establish clear and stable rules for the organic sphere and allow organic producers to fully compete in the Ukrainian domestic and foreign markets, has been specified. Practical value. It was determined that one of the priorities at the present stage of improving the regulatory regulation of organics is the adoption of the State target program for the development of organic production in Ukraine to determine specific stages, directions and mechanisms for the development of organic agricultural production, markets and export potential. Conclusions. It has been proved that the development of the regulatory and legal regulation of the organic sector in Ukraine is the top priority for developing sound basis for the most promising agricultural production system, which can accelerate not only the development of the agricultural sector, but also the national economy of Ukraine in the near future. References 28, table 1, figures 2 .

Key words: European experience, Ukrainian legislation, organic sector, legal regulation, organic products, organic market.

\section{REFERENCES}

1. Artysh, V. I. (2010). "Udoskonalennya systemy derzhavnogo regulyuvannya vyrobnycztva organichnoyi produkciyi v Ukrayini" [Improvement of the system of state regulation of organic production in Ukraine]. Naukovyj visnyk nacionalnogo universytetu bioresursiv i pryrodokorystuvannya Ukrayiny, 145 , pp. 365-370 [in Ukrainian].

2. Berlach, N. A. (2010). "Vdoskonalennya specialnoyi normatyvno-pravovoyi bazy - priorytetnyj chynnyk rozvytku organichnogo silskogo gospodarstva v Ukrayini" [Improvement of the special regulatory and legal framework is a priority factor for the development of organic agriculture in Ukraine]. Forum prava, 1, pp. 19-23 [in Ukrainian].

3. Kapshtyk, M. V. (2012). "Normatyvno-pravove zabezpechennya organichnogo vyrobnycztva $\mathrm{v}$ Ukrayini: problemy ta perspektyvy" [Regulatory and Legal Support of Organic Production in Ukraine]. Agroekologichnyj zhurnal, 1, pp. 25-31 [in Ukrainian].

4. Kobets, M. I. (2004). "Organichne zemlerobstvo v konteksti stalogo rozvytku" [Organic farming in the context of sustainable development]. Proekt "Agrarna polityka dlya lyudskogo rozvytku”. Kyiv [in Ukrainian].
5. Melnyk, V. O. (2018). "Pravove regulyuvannya organichnogo silskogospodarskogo vyrobnycztva v Ukrayini" [Legal Regulation of Organic Agricultural Production in Ukraine]: dys. kand. yur. nauk: 12.00.06 "Zemelne pravo; agrarne pravo; ekologichne pravo; pryrodo-resursne pravo" (yurydychni nauky); Nacionalnyj universytet bioresursiv i pryrodokorystuvannya Ukrayiny. Kyiv [in Ukrainian].

6. Melnychuk, O. F., Melnychuk, M. O. (2017). "Pravove regulyuvannya vyrobnycztva organichnoyi silskogospodarskoyi produkciyi v Ukrayini" [Legal regulation of organic agricultural production in Ukraine]. Ekonomika. Finansy. Menedzhment: aktualni pytannya nauky i praktyky, 5, pp. 98-108 [in Ukrainaian].

7. Novak, N. P. (2016). "Formuvannya i realizaciya strategichnyh zasad rozvytku organichnogo vyrobnycztva u silskogospodarskyh pidpryyemstvah" [Formation and implementation of strategic principles for the development of organic production in agricultural enterprises]. Prychornomorski ekonomichni studiyi, 4, pp. 74-77 [in Ukrainian].

8. Overkovska, T. K. (2017). "Pravovi oznaky organichnogo vyrobnycztva silskogospodarskoyi produkciyi v Ukrayini”" [Legal signs of organic produc- 
tion of agricultural products in Ukraine]. Pidpryyemnycztvo, gospodarstvo i pravo: zagalnoukrayinskyj naukovo-praktychnyj gospodarskopravovyj zhurnal, 11, pp. 94-98 [in Ukrainian].

9. Parkhomenko, M. M. (2011). "Pravove regulyuvannya organichnogo vyrobnycztva v Ukrayini" [Legal regulation of organic production in Ukraine]. Forum prava, 4, pp. 546-552 [in Ukrainian].

10. Piddubna, D. V. (2015). "Pravove zabezpechennya zahystu organichnoyi produkciyi vid genetychno modyfikovanyh organizmiv $\mathrm{v}$ Ukrayini : monografiya" [Legal protection of organic products from genetically modified organisms in Ukraine: monograph]. Kryvyj Rig: Roman Kozlov [in Ukrainian].

11. Rud, V. P. (2018). "Instytucijno-pravove regulyuvannya organichnogo ovochivnycztva" [Institutional and legal regulation of organic vegetable growing]. Intelekt XXI, 4, pp. 82-86 [in Ukrainian].

12. Frolova, N. V. (2016). "Osnovni pravovi zasady organichnogo vyrobnycztva" [Basic legal principles of organic production]. Porivnyalno-analitychne pravo, 6, pp. 142-145 [in Ukrainian].

13. Milovanov, E. V. (2018). "Pravovi zasady regulyuvannya organichnogo vyrobnycztva $\mathrm{v}$ krayinah ES" [Legal principles of regulation of organic production in EU countries]. Ekonomika APK, 5, pp. 117-125 [in Ukrainian].

14. Milovanov, E., Melnyk, S., Demydov, O., Zhylkin, V., Kolesnyk, I., Konyashyn, A., Nishheta, V., Tkachuk, V. (2008). "Dovidnyk standartiv ES shchodo regulyuvannya organichnogo vyrobnycztva ta markuvannya organichnyh produktiv" [Directory of EU standards for the regulation of organic production and labeling of organic products]. Lviv, LA "Piramida" [in Ukrainian].

15. Milovanov, E., Melnyk, S., Demydov, O., Ivashhuk, S., Kolesnyk, I., Konyashyn, A., Netesa, M., Nishhea, V., Poyedynok, M. (2010). "Dovidnyk standartiv ES shhodo regulyuvannya organichnogo vyrobnycztva ta markuvannya organichnyh produktiv" [Directory of EU standards for regulating organic production and labeling of organic products]. Lviv: LA "Piramida" [in Ukrainian].

16. Organic v Ukraini [Organic in Ukraine] (2018). Oficijnyj sajt Federaciyi organichnogo ruhu Ukrayiny. Retrieved from: http://organic.com.ua/uk/homepage/ 2010-01-26-13-42-29 [in Ukrainian].

17. "Konstytuciya Ukrayiny [The Constitution of Ukraine] (1996). Vidomosti Verkhovnoyi Rady Ukrayiny", 30, st. 141. Retrieved from: http://zakon.rada.gov.ua/laws/show/254k/96-vr [in Ukrainian].

18. "Pro osnovni pryncypy ta vymogy do organichnogo vyrobnycztva, obigu ta markuvannya organichnoyi produkciyi" [About the basic principles and requirements for organic production, circulation and labeling of organic products]: Zakon Ukrayiny vid 10 lypnya 2018 r. No 2496-VIII Baza danyh "Zakonodavstvo Ukrayiny" / VR Ukrayiny. Retrieved from: http://zakon.rada.gov.ua/laws/show/2496-19 [in
Ukrainian].

19. "Pro zatverdzhennya derzhavnogo logotypa dlya organichnoyi produkciyi" [About Approval of the State Logo for Organic Products]: Nakaz Ministerstva agrarnoyi polityky ta prodovolstva Ukrayiny vid 22.02.2019 r. \# 67. Retrieved from: https://zakon.rada.gov.ua/laws/show/z0261-19 [in Ukrainian].

20. "Pro zatverdzhennya derzhavnogo logotypu dlya organichnoyi produkciyi (syrovyny)" [About approval of the state logo for organic products (raw materials)]: Nakaz Ministerstva agrarnoyi polityky ta prodovolstva Ukrayiny vid 25.12.2015. No 495. Retrieved from: http://zakon.rada.gov.ua/laws/show/z0099-16\#n15 [in Ukrainian].

21. "Organichnyj" Zakon: Vstanovleni vymogy do organiv sertyfikaciyi organichnoyi produkciyi" ["Organic" Law: Established Requirements for Organic Certification Authorities] (2018).: Oficijnyj sajt Ministerstva agrarnoyi polityky ta prodovolstva Ukrayiny. Retrieved from: http://www.minagro.gov.ua/node/26227

22. "Strategiya rozvytku agrarnogo sektoru «3+5»" [Strategy for Agrarian Sector Development "3 + 5"]. Oficijnyj sajt Ministerstva agrarnoyi polityky ta prodovolstva Ukrayiny. Retrieved from: http://minagro.gov.ua/system/files/3\%205\%20final.pdf [in Ukrainian].

23. Kapshtyk, M. V., Kotyrlo, O. O. (2007). "Dovidnyk mizhnarodnyh standartiv dlya organichnogo agrovyrobnycztva" [Directory of International Standards for Organic Farming]. Navchalno-koordynacijnyj centr silskogospodarskyh doradchyh sluzhb, Kyiv, SPD Gorobecz G.S. [in Ukrainian].

24. Milovanov, E. (2018). "Dovidnyk standartiv ES shhodo regulyuvannya organichnogo vyrobnycztva ta markuvannya organichnyh produktiv" [Directory of EU Standards for Organic Production and Labeling of Organic Products]. Lviv: VK "ARS" [in Ukrainian].

25. Melnyk, V. O. (2014). "Zarubizhnyj dosvid pravovogo regulyuvannya organichnogo vyrobnycztva (porivnyalno-pravovyj aspekt)" [Foreign experience of legal regulation of organic production (comparative legal aspect)]. Naukovyj visnyk Nacionalnogo universytetu bioresursiv i pryrodokorystuvannya Ukrayiny, 197, 2, pp. 79-90 [in Ukrainian].

26. Milovanov, E., Martynyuk, M., Kovalova, O., Hodakivska, O. "Regionalna pidtrymka organichnogo vyrobnycztva v Ukrayini”" [Regional support for organic production in Ukraine]. Kyiv: Organic Print [in Ukrainian].

27. Official website of European Union law [Official website of European Union law]. Retrieved from: http://eur-lex.europa.eu [in English].

28. Willer, H., Lernoud, J. (2019). "The World of Organic Agriculture. Statistics and Emerging trends". FiBL\&IFOAM - Organic International. Germany: Medienhaus Plump [in English]. 